\title{
Lexicography, Terminography and Copyright
}

\author{
Mariëtta Alberts and Michiel Jooste \\ National Terminology Services, Pretoria, South Africa
}

\begin{abstract}
The focus of this article is on copyright issues with specific reference to lexicography and terminography. Lexicographers and terminographers are in the peculiar position of being both creators of copyrightable products and users of copyrighted products. An inventory of accrued rights, the nature of dictionaries as subjects of copyright, national laws and international conventions, terminographical and lexicographical practice, the copyright status of dictionary elements, as well as infringement pitfalls, is made in order to propose guidelines on the legal position of the compilation and publishing of dictionaries. Electronic publications and dissemination on the Internet is considered and discussed, and contractual agreements protecting mutual rights is offered as a final conclusion.
\end{abstract}

Keywords: AUTHOR'S RIGHT (COPYRIGHT), COPYRIGHT (AUTHOR'S RIGHT), COPYRIGHT INFRINGEMENT, COPYRIGHT ISSUE, COPYRIGHT LAW, COPYRIGHTABLE PRODUCT, COPYRIGHTED PRODUCT, DATABASE STORAGE SYSTEM, DENOMINATOR, ECONOMIC RIGHT, ELECTRONIC COMMUNICATION NETWORK, FAIR USE, INFRINGEMENT, INTELLECTUAL PROPERTY, INTELLECTUAL PROPERTY RIGHT, LEXICOGRAPHER, LEXICOGRAPHY, MACROSTRUCTURE, MICROSTRUCTURE, MORAL RIGHT, TANGIBLE MEDIUM, TERMINOGRAPHER, TERMINOGRAPHY, TERMINOLOGIST, TERMINOLOGY

Opsomming: Leksikografie, terminografie en outeursreg. In hierdie artikel word gefokus op outeursregkwessies met spesifieke verwysing na die leksikografie en terminografie. Leksikograwe en terminograwe bevind hulle in 'n vreemde situasie deurdat hulle sowel skeppers van outeursregbare produkte is as gebruikers van outeursberegte produkte. 'n Inventaris word opgestel van toegevalle regte, die aard van woordeboeke as onderworpe aan outeursreg, nasionale wette en internasionale konvensies, terminografiese en leksikografiese praktyk, die outeursregstatus van woordeboekelemente, asook van slaggate rakende outeursregskending ten einde riglyne vir die regsposisie van die samestelling en publikasie van woordeboeke voor te stel. Elektroniese publikasies en verspreiding op die Internet word oorweeg en bespreek, en ten slotte word kontraktuele ooreenkomste wat wedersydse regte beskerm, geopper.

Sleutelwoorde: OUTEURSREG (KOPIEREG), KOPIEREG (OUTEURSREG), OUTEURSREGSKENDING, OUTEURSREGKWESSIE (OUTEURSREGVRAAGSTUK), OUTEURSREGWET, OUTEURSREGBARE PRODUK, OUTEURSBEREGTE PRODUK, DATABASISBERGSTELSEL, AANDUIDER, EKONOMIESE REG, ELEKTRONIESE KOMMUNIKASTENETWERK, BILLIKE GEBRUIK, SKENDING, INTELLEKTUELE EIENDOM, INTELLEKTUELE EIENDOMSREG, LEKSIKOGRAAF, LEKSIKOGRAFIE, MAKROSTRUKTUUR, MIKROSTRUKTUUR, MORELE REG, 
TASBARE MEDIUM, TERMINOGRAAF, TERMINOGRAFIE, TERMINOLOOG, TERMINOLOGIE

\section{Introduction}

Information practitioners around the globe are confronted with several issues regarding copyright and the fruits of their labour. The current worldwide discussion of intellectual property rights has been prompted by a shift from fairly clear and predictable copyright laws with regard to printed works, to legal uncertainty in electronic communication networks and database storage systems. The number of recently held seminars, congresses, workshops and published articles on various issues relating to copyright are proof of this.

The focus of this article is on copyright issues with specific reference to lexicography and terminography, involving lexicographers and terminographers as being both creators of copyrightable products, and users of copyrighted products. Two angles of approach are inherently called for in order to determine the legal position of the lexicographer/terminographer in this dual capacity, these angles being best illustrated by the following two questions:

- What rights do lexicographers/terminographers accrue when compiling and publishing dictionaries?

- What may lexicographers/terminographers do when compiling and publishing dictionaries without infringing copyright?

During the course of research for this article, it became clear that general, broad and very often technically vague guidelines regarding the lexicographer's/ terminographer's legal position are abundant, being defined in terms of national copyright laws and statutes (for example the South African Copyright Act 98 of 1978), international agreements on intellectual property rights (for example the Berne Convention of 1979) and deductions made from papers presented at various conferences (for example the Report of the Working Group on Intellectual Property Rights of 1995).

Language practitioners are positioned between the highly technical rules of copyright law on the one hand and the common practice of their trade of reproducing, quoting and copying from sources on the other hand:

It is highly unlikely that even the fine-tuned expert definitions found in national and international standards would qualify as ... unique expression. Standard definitions are frequently reused in other standards, in general and technical texts, and in terminology databases ... (Wright 1996: 2)

The principles of "fair use", "right of recognition of authorship", "infringement" 
and the multitude of legal formulae and legal terminology governing copyright do not spell out in clear and understandable language what the lexicographer/ terminographer should or should not do to prevent infringing or being infringed upon.

To avoid being yet another theoretical voice in the discourse, this article will try to cover several practical problems that lexicographers/terminographers may encounter in the course of compiling a dictionary. These problems stem from the very nature of a dictionary as a specific kind of intellectual property type, because of aspects such as typology, structure and tangible manifestation of the content, the nature of the compilation process - in fact, the essentialia of what distinguishes a dictionary from other printed matter.

It is not the purpose of this article to come up with any revolutionary findings, but rather to make an inventory of the current state of affairs by providing suggestions for specific problems, as substantiated by case law, proceedings of seminars and workshops and articles published in magazines. We hope thereby to illustrate what is permissible within the scope of copyright coverage for lexicographers/terminographers with regard to their products. However, it must be made clear from the start that where copyright is concerned, there are no hard and fast rules as every case will have to be decided by a court of law.

\section{What is copyright?}

Copyright is, giving a very broad definition, "the right that gives an author or any other entitled person, the sole right to commit certain acts regarding intellectual property of their own creation, especially acts regarding the duplication thereof" (Copeling 1978: 77). Ownership is granted only once the content has been made material by putting it in a tangible medium. The rights accrued by this ownership must be and are protected by law (Copeling 1978: 93).

In South Africa for example, the Copyright Act 98 of 1978 (as amended), and its regulations, governs this field. Copyright is also territorial (Wright 1996: 2). This means that copyright law technically only extends as far as the law permits it to, and as far as the territory permits the law to rule. In other words, copyright law as it exists in South Africa, is unique to South Africa, since only South Africa is governed by this statute. However, since published works are being used all over the world, there is a need to protect the rights of authors across national borders.

Intellectual property was only legally recognised as a theory in England in 1709 (Galinski 1996: 7). As the concept of intellectual property developed, various agreements were called upon to regulate universal copyright requirements. The Berne Convention for the Protection of Works of Literature and Art, completed in 1896, was the first major international agreement on authors' rights. All countries signing the accord are bound to the provisions of that agreement, in order to establish mutual enforcement of copyright between member countries. 
The most important convention that binds us today, is still the Berne Convention, as ratified in Paris on 24 July 1971. For political reasons South Africa was not a party to this convention in 1971. Since South Africa was, however, party to the Berne Convention as revised in Brussels in 1948, the provisions of the Paris text had been administratively ratified. This means that we are bound to the provisions of the latter, since South Africa remained a member of the convention and did not indicate otherwise (Copeling 1978: 9).

\section{The Berne Convention}

The Berne Convention makes provision for the protection of authors' moral and economic rights across national borders. The following provisions are of special interest for the aim of this article:

Article 2 (3)

Translations, adaptations, arrangements ... and other alterations of a literary or artistic work shall be protected as original works without prejudice to the copyright in the original work.

\section{Article 2 (5)}

Collections of literary or artistic works ... which, by reason of the selection and arrangement of their contents, constitute intellectual creations, shall be protected as such, without prejudice to the copyright in each of the works forming part of such collections.

\section{Article 3 (3)}

The expression "published works" means works published with the consent of their authors, whatever may be the means of manufacture of the copies, provided that the availability of such copies has been such as to satisfy the reasonable requirements of the public, having regard to the nature of the work.

\section{Article $6^{\text {bis }}(1) \&(2)$}

Independently of the author's economic rights, and even after the transfer of the said rights, the author shall have the right to claim authorship of the work and to object to any distortion, mutilation or other modification of, or other derogatory action in relation to, the said work, which would be prejudicial to his honour or reputation. The rights granted to the author ... shall, after his death, be maintained, at least until the expiry of the economic rights. 


\section{Article 8}

Authors of literary works protected by this Convention shall enjoy the exclusive right of making and of authorizing the translation of their works throughout the term of protection of their rights in the original works.

\section{Article 9 (1)}

Authors of literary and artistic works shall have the exclusive right of authorizing the reproduction of these works, in any manner or form.

\section{Article 9 (2)}

It shall be a matter for legislation ... to permit the reproduction of such works in certain special cases, provided that such reproduction does not conflict with a normal exploitation of the work and does not unreasonably prejudice the legitimate interests of the author.

\section{Article $10(1)$}

It shall be permissible to make quotations from a work which has already been lawfully made available to the public, provided that their making is compatible with fair practice, and their extent does not exceed that justified by the purpose ...

\section{Article 12}

Authors ... shall enjoy the exclusive right of authorizing adaptations, arrangements and other alterations of their works.

\section{Common copyright denominators ${ }^{1}$}

Although national laws of countries may show differences, certain common denominators, resulting from said agreements such as the Berne Convention,

1 These denominators are given as a summary and have been obtained from the following sources: Wright 1996; Galinski 1996; Felber 1986; Templeton 1996; South African Copyright Act 98 of 1978 (as amended); Report of the AAU Task Force on Intellectual Property Rights in an Electronic Environment 1994; United States Copyright Protection Act of 1988; General Agreement on Tariffs and Trade (GATT) 1994; Grünbuch der Kommission der Europäischen Gemeinschaften 1995; correspondence with the Chief Editor: Macquarie Dictionary (Australia); the Registrar: Patents, Hallmarks, Authors' Rights and Models (South Africa); and the Publishing Consultant: South African Press Association (South Africa). 
common law and civil law are distinguishable. By comparing these, it is thus possible to construe a "universal copyright law" that can be assumed to be applicable irrespective of where a work was copyrighted. These denominators should be acknowledged, developed and nurtured. Once these denominators are globally accepted, they can be applied to the fields of lexicography and terminography in order to establish a standardised lexicographical code of conduct. The latter should promote the reusability and dissemination of information, but at the same time protect authors' rights in a clear and universally recognised set of rules.

\subsection{Requirements for copyright to exist}

Ideas and information themselves are not protected by copyright. Ideas and information must be concretised, in other words, fixed in a tangible medium, consisting of both content and internal and external form. This would include any carrier or embodiment of the work, such as printed matter, electronic media and audiovisual media, amongst others.

Once an idea is concretised, copyright naturally exists on the product, and no explicit indication that copyright exists is required. The work must however be original in character, with character referring both to the original expression and to the arrangement of the knowledge in the work. It should also be noted that originality is defined in very broad terms, requiring only that the work emanates from the author and is not copied - it is thus only applicable to original skill or labour in execution, and not original thought.

\subsection{Subjects of copyright}

In South Africa, the Copyright Act divides subjects into two broad categories, namely "works that traditionally (are) the subject of copyright" and "works regarded as a medium of communication". Works that traditionally are the subject of copyright may include literary, artistic and musical works. Literary works include, irrespective of literary quality (as long as they are only "written") the following:

- novels, stories and poetical works

- dramatic works, stage directions, film scenarios and broadcasting scripts

- textbooks, treatises, histories, biographies, essays and articles

- encyclopaedias and dictionaries

- letters, reports and memoranda

- lectures, speeches and sermons

- tables and compilations 
It should be noted that the act is not very specific in distinguishing between these various types of literary products. These categories should be interpreted very broadly. One can distinguish between works from all areas of literature, the sciences, practical daily life, as well as adaptations, derivative works, translations and collections.

\subsection{Authors' rights}

Once copyrighted, certain authors' rights are created and include:

(a) Economic rights

- the right of publication

- derivative rights

- the right of use

- the right of access to the original or duplication master

- the right to claim compensation for the licensing of duplication for commercial purposes

- the right to transfer to a third party

(b) Moral rights

- the right of recognition of authorship

- the right to prevent misrepresentation or unauthorised modification

\subsection{Infringement on copyright}

Infringement occurs when somebody commits an act that is the sole prerogative of the copyright holder without the permission of the copyright holder. Acts of infringement are the translation, reproduction, publishing, performing, broadcasting or adapting of a literary work in any manner or form, without the consent of the copyright holder. Actual copying of the work, or a substantial portion thereof, must take place. A substantial portion depends both on how much of the work is copied and on the quality of the portions copied, the latter being of greater importance than the former.

\subsection{Defences to infringement}

The South African Act 98 of 1978 makes provision for certain general exceptions provided that there is "fair dealing" such as the inclusion of short excerpts from a copyrighted work in another work for the purposes of criticism or 
review, or reporting of current events, provided that the extent of the excerpts shall not exceed the extent justified by the purpose and that the source shall be mentioned, as well as the name of the author if it appears on the work. Proper citation is called for, because reuse without proper citation constitutes plagiarism (Wright 1996: 2). Copyright requires a work to be the original thought and expression of the author, which can be difficult to express in very short excerpts such as dictionary entries. Wright (1996: 2), as already mentioned, argues that "standard definitions are frequently re-used in other standards, in general and technical texts, and in terminology databases with attribution under the provisions of fair use".

When the right of the original owner to the exploitation of the work is compromised by excessive quotation or reuse of copyrighted material, fair dealing becomes questionable. This would definitely be the case if an entire standard was rearranged and incorporated into a terminological collection (see par. 6 below). Wright (1996: 2) further points out that fair dealing would not be questioned when "the extraction of a subset of terms from standard or other works (involve) the inclusion of random texts and definitions documenting the affected concepts such that the resulting new material does not compromise a substantial percentage of the original and the arrangement is significantly different". Since both lexicographers and terminographers are highly dependent on the use of sources to compile dictionaries, the proper incorporation of these sources is of utmost importance. This practice is however easier to apply in lexicography than terminography, as will be explained.

\section{Terminography and lexicography}

In studying various articles on what is copyrightable and what not, it seems that copyright may be added as yet another category to the list of differences between terminography and lexicography. It is acknowledged that no statute or convention makes any explicit distinction between lexicographical and terminographical collections where copyright is concerned. However, a thorough comparison proves that the coverage of fair use definitely differs in applicability. One may find that the same act of incorporating material from another work is rebutted or proved as infringement in a court of law, depending on the reuse of a work for lexicographical or terminographical purposes.

If one looks at what is not copyrightable, some interesting conclusions can be made. Only original works of authorship are protected, not mere original thought. Trittipo (1996: 369) states that "ideas and facts are true regardless whether any person knows them or not, and they owe their origin to the way the world is, not to any author". One also needs to consider the idea-expression dichotomy which amounts to a rule that if the "idea" and its "expression" is inseparable, copying the expression will not be barred, since protecting the "expression" in such circumstances would confer a monopoly of the "idea" on 
the copyright owner (Trittipo 1996: 369).

In the same way, individual words in general language and most terms in special languages are the common property of all speakers, since the idea cannot be separated from the way it is expressed in a single word. In terminology, lengthy phrases are also considered to be terms and cannot be expressed in any other way but in the acknowledged phrase as construed by terminologists and subject specialists. Wright (1996: 2) states that "terminological principles require substantial supportive material in terminological entries in the form of definitions and contextual references". Ideally, these materials should not be original, but rather taken from authoritative sources. Thus, each entry is very likely to contain one, or in many cases, numerous references taken from published, pro. priety or even standardised works (Wright 1996:3).

Because terminology deals with the exact coining of concepts, these entries should not be modified to circumvent copyright ownership of the source material, since it would be unethical and terminographically wrong. Terminologists want the word-for-word rendering of standardised definitions and live contexts. It is obvious that within a specific subject field these terms, definitions and contexts are (and are supposed to be) the same. There is no way that these concepts should be allowed to be expressed differently, otherwise it would defy the whole purpose of terminology, namely that of exact and precise communication with a standardised technical vocabulary (terminology) within a specific subject field. An example of this would be the following nuclear term:

curie a unit of radioactivity ... defined as the quantity of any radioactive nuclide in which the number of disintegrations per second is $37.00 \mathrm{x}$ 10. (Jerrard-McNeill 1972 $: 32$ )

Two obvious problems are apparent at this stage: terminology per se is not copyrightable and the reuse of terminology entries is inevitable. How does one provide a dictionary of, for example, nuclear terms in several languages, and who owns what, if all the terms and definitions thereof are universally descriptive of the same concepts in the subject field - irrespective of language used?

Trittipo (1996: 368) argues that "mere lists such as for parts and associated parts numbers, may not be copyrightable ... when the selection of terms on the list is determined mainly by facts or user expectations, rather than by the list maker's discretion, since a list has to list every relevant or replaceable part". He argues further that where there is no real choice of what to include and select, no copyright exists on such a document. If selection and choice depend on the discretion of the author, copyright does exist. Common terminographical practice frequently involves mere lists of terms in subject domains in various languages. According to this principle, no copyright exists on such lists of terms.

This statement is supported by the decision in Feist Publications, Inc. vs. Rural Telephone Service Co., Inc., 499 US 340 (1991) which ruled that databases that consist of purely factual information (such as telephone directories) cannot 
be copyrighted. However, it stated obiter dicta that databases that select, organise or arrange these facts in a certain manner (e.g. by using terminographical principles in order to compile a list of bookbinding terms), are copyrightable. Theoretical literature also suggests that within terminology the "smallest meaningful units" are copyrightable, as well as the mechanisms used for accessing and updating these units. These units or data element categories are described in ISO 12620.2 and are thus already set as a standard by an authoritative body.

One can therefore safely conclude that copyright does exist in every single separate element in any tangible medium in which terminology is expressed. A practical problem results from this fact: dictionaries and lexicographical/terminographical databases are either derivative works, compilations or translations of terminology already excerpted and recorded in other languages. Since copyright exists on the original dictionary or database and it is expected of a terminologist to provide a word-for-word description of the standardised definition of the concept, conflict of interest is inevitable. Wright (1996: 1) argues that there is no limit to a terminologist's right to report a term or any set of terms in a terminological resource, but that "precise unauthorised reproduction of a given set of terms together with their definitions ... without further valueadded information or other modification, would in all likelihood constitute an infringement of copyright".

In subject fields with a large vocabulary it does not necessarily pose a problem, since a variable degree of selection is possible and room is left for choice of selection and arrangement. It should be expected that more than one original dictionary within such a subject field may appear (e.g. a dictionary of Commercial Science). In subject fields with a small vocabulary, the copyright owner has little to no protection, since fair dealing provides that if no room is left for the choice of selection at the discretion of the author, no copyright can exist on such a publication.

One may argue that the selection of terms in a subject field involves original thought in execution and is therefore protected, since selection entails the application of certain terminology skills. However, fair dealing would allow a terminologist to use these terms as well as their definitions to a large extent. The concept and its expression in the code of language are also inseparable and it belongs to the respective discourse community, thus it cannot be copyrighted. In addition to this, terminology practice requires the standardised rendering of conceptual information, limiting original expression to a large extent. One is left with the conclusion that ownership of the published material would only be protected as regards layout, typology and aspects not referring to the content and defining of the terminology (vocabulary). In fact, one may go so far as to say that the reuse of the entire macro- and microstructure of a technical dictionary of a minor language, would still be allowed under current rules.

In lexicography, the theoretical arguments seem to be easier, but the issue of copyright infringement is just as complex. As was said earlier, no copyright exists on general words in a language. However, the countless ways in which 
one can present, select and arrange these words in a dictionary, ensures that every dictionary can and should be an original work that is protected when it is
put on paper (or whatever medium is chosen by the author).

As a result, it would not be fair and reasonable to take the macrostructure of someone else's dictionary and use it as it is, even if one provides one's own microstructure. The headword list, layout of an entry, components of defini. tions, etc. are essential to a particular dictionary and cannot be copied to another dictionary without infringing copyright (RJ Romme vs. Van Dale Lexi. cographie, 1994). This principle would be applicable to a single dictionary entry too, where room for choice is left in defining and explaining a lemma. If certain definitions seem to correlate or were copied, an infringement defence may be that there can only be so much room to move within a definition. Copyright does cover all the separate dictionary elements, but one cannot prove that someone has infringed copyright if one finds, for example, one illustrative sentence that is the same. One needs to demonstrate a pattern of borrowing. ${ }^{2}$

\section{Derivative works and compilations}

Both lexicography. and terminography depend on other sources for its content. If a completely original work (for example a list of terms compiled by the developers of new technologies requiring neologisms) is not created, dictionaries and products of lexicography and terminology can be divided into derivative works and compilations.

The US Copyright Protection Act of 1988 defines a derivative work as a work "based upon one or more pre-existing works, such as a translation ... dramatisation, fictionalisation, motion picture version, sound recording ... abridgement, condensation, or any other form in which a work may be recast, transformed or adapted". The Berne Convention also requires that member countries accord to authors the exclusive right of translation (Article 8). The rights to make and to authorise the making of derivative works (such as translations) are among the exclusive rights of an author. According to Trittipo (1996: 369), a derivative work that is created without the authorisation of the original's copyright holder, and without some defence such as fair dealing, is generally not entitled to copyright protection. It is however curious to note that section 2 (3) of the South African Copyright Act 98 of 1978 states that "a work shall not be ineligible for copyright by reason only that the making of the work ... involved an infringement of copyright in some other work". Thus, an unauthorised transformation of a protected work is still protected under South African copyright

2 Mention must here be made of the advice of Ms S. Butler from the Macquarie Dictionary, Australia, in this regard. 
law, and may not be infringed upon by someone else.

An unauthorised translation, transformation or adaptation of an original work should be strongly discouraged, and we are of the opinion that the South African copyright law is lacking in that it does not adequately protect authors of original works by granting protection to such unauthorised adaptations. If there is no copyright on the infringing work, it means that anyone can copy it lawfully, to the prejudice of the author of the original work. This state of affairs is also in contrast with the spirit of Article 8 of the Berne Convention which grants authors the exclusive right of translation and the authorisation thereof.

Once permission is obtained from an author to make a translation of a work, this translation is original because there is significant room for choice in how to translate most things. As Trittipo (1996: 370) states: "a translator's goal is to duplicate an original's meaning ... but a translator also seeks to duplicate tone and feeling, and these are matters of expression".

The majority of dictionaries are compiled solely for the purpose of providing translated equivalents in a target language from words or terms in a preexisting vocabulary in a source language. All bi- and multilingual dictionaries fall into this category. If a translation of a lexicographical or terminological collection is made without the permission of the original author, the copyright in the translation should vest in the author of the original work, and not in the translation. Since the South African copyright law indicates the contrary, this argument bears no significance and will not be referred to again. In general, once permission has been obtained, the translator becomes the sole author of that product, with the same degree of authors' rights and copyright protection as any author of an original protected work. This rule may however be altered by, and is subject to contractual arrangements made between the various parties involved in the process (Norman 1994: 460).

In the light of the above-mentioned discussion on the unique nature of terminologies in certain subject fields, it appears that a substantial amount of translation of terminologies may be allowed under the principle of fair dealing, since terminology defines concepts (which cannot be protected) and may consist of very small or technically specific vocabularies. Furthermore, terminology practice implies the excerpting of terms, the coining of terms and term equivalents, and the naming and defining of concepts. Terminologists do not translate. Terminologists are always supposed to use the concept as basis and then transfer the exact meaning of that concept into the chosen target language (Cluver 1992: 35). Since a terminologist hardly ever has to express "tone and feeling", but rather provide the exact meaning, it is doubtful that terminologists are subject to authorisation in order to compile their technical dictionaries. One would however infringe copyright if mere translations of terms (and no coining of terms for concepts) are provided, or if mere translations of definitions are given where room for choice of original expression is possible, but ignored. With regard to lexicography, it is obvious that general language dictionaries may not be translated without authorisation from the owner of the source. 
Most terminological and lexicographical collections can be viewed as compilations (Wright 1996: 2) which can be defined as "formed by the collection and assembling of pre-existing materials or data that are selected, co-ordinated, or arranged in such a way that the resulting work as a whole constitutes an original work of authorship" (US Copyright Act Protection of 1988). Creators of terminological and lexicographical collections can therefore claim copyright protection for their works, taking into consideration the above-mentioned restrictions with regard to the nature of terminological and lexicographical work. Infringement would once again depend on fair dealing. What exactly constitutes fair dealing has been the subject of ongoing debate, and may depend on whether a substantial portion of the source is used in the compilation, whether proper citation is given, whether a pattern of borrowing can be established, etc.

\section{Citation}

Since general language dictionaries make abundant use of citations in order to explain the context in which words may occur, and technical dictionaries depend on authoritative and standardised sources to capture and define the exact meaning of concepts, both lexicographical and terminological products should pay attention to providing the proper references for these sources. Common practice usually indicates the inclusion of a bibliography of sources as front or back matter. Citations are usually so short that they are considered to be out of copyright. If one needs or wants to use substantial citations, ways of proper references whence the citations are taken, should be adhered to. Usually the citation will be given with the title and date of the source, because this is the important information required to give the person reading the entries access to the complete bibliography. Wright (1995: 256) also supports the idea of a device which refers a reader to a bibliography listing the sources used to compile dictionary entries: "Source identifiers should be short codes that act as pointers that link to targets, i.e. bibliographical entries that occur once in the system. The native procedure for any system is not a serious problem so long as it remains possible to extract bibliographical data and express it as end matter."

\section{Copyrightable dictionary elements}

The following table may serve as a general guide to determine what elements are copyrightable in lexicographical and terminographical entries: 


\begin{tabular}{|c|c|c|c|}
\hline \multicolumn{4}{|c|}{$\begin{array}{l}\text { LEXICOGRAPHY AND TERMINOGRAPHY - } \\
\text { GENERAL COPYRIGHT GUIDELINES TO SEPARATE DICTIONARY ENTRIES }\end{array}$} \\
\hline \multicolumn{2}{|c|}{ TERMINOLOGY } & \multicolumn{2}{|c|}{ LEXICOGRAPHY } \\
\hline COPYRIGHT & NO COPYRIGHT & COPYRIGHT & NO COPYRIGHT \\
\hline $\begin{array}{l}\text { Definitions (if a degree of } \\
\text { choice in original expression } \\
\text { is available) }\end{array}$ & All terms & Microstructure & All lemmata \\
\hline $\begin{array}{l}\text { Macrostructure of major } \\
\text { languages }\end{array}$ & $\begin{array}{c}\text { Definitions of } \\
\text { definition-specific } \\
\text { concepts or } \\
\text { technically specific } \\
\text { languages }\end{array}$ & Macrostructure & Collocations \\
\hline $\begin{array}{l}\text { Microstructure of major } \\
\text { languages }\end{array}$ & $\begin{array}{c}\text { Context indicators of } \\
\text { context specific } \\
\text { concepts }\end{array}$ & Definitions & $\begin{array}{l}\text { Definitions where } \\
\text { no room is left for } \\
\text { original expression }\end{array}$ \\
\hline $\begin{array}{l}\text { Context indicators of major } \\
\text { languages }\end{array}$ & $\begin{array}{l}\text { Microstructure of } \\
\text { minor languages }\end{array}$ & $\begin{array}{l}\text { Pragmatic } \\
\text { information }\end{array}$ & $\begin{array}{l}\text { Grammatical } \\
\text { information }\end{array}$ \\
\hline Layout & $\begin{array}{l}\text { Macrostructure of } \\
\text { minor languages }\end{array}$ & Layout & Fixed expressions \\
\hline Typology & $\begin{array}{l}\text { Translations of } \\
\text { terminological } \\
\text { vocabularies }\end{array}$ & Typology & \\
\hline $\begin{array}{l}\text { Example sentences and } \\
\text { encyclopaedic information }\end{array}$ & $\begin{array}{l}\text { Grammatical } \\
\text { information }\end{array}$ & $\begin{array}{c}\text { Encyciopaedic } \\
\text { information and } \\
\text { example sentences }\end{array}$ & \\
\hline
\end{tabular}

\section{The Internet}

There are quite a number of on-line dictionaries and terminology databases available on the Internet today. Since copyright and the Internet is a general concern and subject of ongoing debate worldwide, this issue will only be touched on very briefly.

It must be remembered that all works are protected the moment they are written, and no copyright notice is required. Postings (information put on the Internet) are not granted to the public domain, and do not grant any user permission to do further copying except the kind of copying that might be expected in the ordinary flow of the Internet, unless otherwise indicated by the author. If works are used or quoted that are published on the Internet, proper and due reference can be given by mentioning the name of the author and the URL (address of the document), or the e-mail address. If no creation or publishing date is provided in the posting, it is advised that the date of one's using of the posting be given.

It is clear that as far as terminology and lexicography are concerned, existing copyright law also applies to documents on the Internet. As was said ear- 
lier, all works should be fixed in a tangible medium before copyright exists in such a publication. This would include any carrier or embodiment of the work, including those published on the Internet. Note that, apart from copying, publishing of another's work as one's own is also an act of copyright infringement.

Thus similarly, terminographical and lexicographical collections will be treated according to the arguments put forward in this article. The extent of protection of a work is not altered by the medium in which it is published. One can therefore not take someone else's dictionary and put it on the Internet without obtaining permission from the author, or create databases through compilation and ignoring the rules of infringement as stated in statutes and legal practice. One cannot typeset a protected work and post it on the Internet (even though one does present it as the work of the author) without the permission of the author, since that would be the same as copying a work and distributing it for all to use and see, resulting in a possible infringement of the author's economic rights. One may argue that one of the main goals of the Internet is to disseminate information as widely and as freely possible. However true this may be, it does not justify the blatant infringing of authors' rights and robbing authors of their livelihood for the convenience of the information society.

The issue of copyright and the Internet is in a very early stage of its evolvement, and it is being worked on and discussed by people all over the world. As far as information on the Internet goes, copyright does exist as explained, but infringements cannot effectively be prevented or sanctioned. It is therefore one's own responsibility to ensure the protection of information granted to the Internet domain, and use the information highway in a climate of mutual trust and ethic responsibility.

Copyright protection is universally recognised as the best form of legal protection for both the old and new categories of works. Copyright therefore still plays a central role in the digital world of computer programs and databases.

GATT, the agreement on Trade-Related Aspects of Intellectual Property Rights (TRIPS), states clearly that both computer programs, whether in source or object code, and databases are protected by copyright, subject to the fundamental requirement that they be original in the sense that they are the author's own intellectual creation (Gervais 1995: 1).

Article 10 of TRIPS reads as follows:

\section{Computer Programs and Compilations of Data}

1. Computer programs, whether in source or object code, shall be protected as literary works under the Berne Convention (1971).

2. Compilations of data or other material, whether in machine readable or other form, which by reason of the selection or arrangement of their contents constitute intellectual creations shall be protected as such. Such protection, which shall not extend to the data or material itself, shall be without prejudice to any copyright subsisting in the data or material itself. 
Gervais (1995: 1) clearly states that "what is true of these new categories of works is also true of the more traditional ones, most of which are expressly mentioned in Article 2 of the Berne Convention".

Since the works mentioned in this article will thus continue to be protected by copyright worldwide under the Berne Convention, the TRIPS agreement and the Universal Copyright Convention, one should, according to Gervais (1995: 1), rather determine which rights apply to the information highway (and whether any new rights are needed) and how they are going to be enforced and administered.

Copyright is composed of a bundle of parallel rights and this has implications for copyright on the information highway:

- The right of reproduction authorises or prohibits the making of a copy of a work or a substantial part thereof in any form. Copying was originally intended to cover incidental private copying and "was not conceived as a main mode for disseminating works in the way that is likely to become prevalent on the information highway" (Gervais 1995: 2).

- The right of communication to the public is the act of making a work available in any manner to persons not restricted to specific individuals belonging to the family circle. Any form of transmission of information, whether interactive or not, can be considered as an act of public performance under the Berne Convention (Gervais 1995: 2).

- The (moral) right of integrity recognised by the Berne Convention, as well as the (economic) right of adaptation will be affected when works transmitted over the digital highways are manipulated (changed). Gervais (1995: 2) argues that in cases where changes give rise to a new work, authorisation from the rights holder of the original work is necessary to use the new work.

- Original compilations of works and other data are protected by copyright as explained previously. According to Gervais (1995: 2) this protection still applies when the contents are downloaded even in part via the digital highways. In some cases, copyright protection may be complemented by a sui generis right.

Gervais (1995: 2) states that "copyright in its present form covers all forms of exploitation, present and future, on the information highways".

\section{Administration and enforcement of copyright on the information highway}

As regards dissemination of protected works by various service providers on the World Wide Web (WWW), these works will have to be administered properly. According to Gervais (1995: 3) database operators will pay and report to collective administration organisations representing rights holders according to negotiated or fixed tariff sister organisations based on the use of data. Central 
clearing houses which will have access to information from almost all countries, as well as to specialised licensing sources could search for rights clearance on behalf of the producers of media and perhaps even negotiate on their behalf. The producer need not deal with these matters him-/herself.

The challenge posed to rights holders is to offer a fully digital worldwide administration system for transmission of works to the public and the reproduction of such works. They should also offer single sources for licensing for multimedia productions. This will, according to Gervais (1995: 4) require a uniform subcoding system and global Electronic Data Interchange (EDI) standards.

Gervais (1995: 4) states: "Over the past 109 years (since the inception of the Berne Convention), each technological change (the invention of cinema, of broadcasting, of sound recordings, of computer programs, etc.) has prompted demands to 'start from scratch'. The information superhighways are no exception. Yet in all previous cases, the Convention has continued to apply and will continue to do so. The works involved are protected under the Convention and the national laws of approximately 150 countries. Moreover, the transmission of works over the information highway and their reuse are covered by existing rights."

\section{Concluding remarks}

This article aimed to provide language practitioners working in the fields of terminology and lexicography certain guidelines concerning copyright. These should be viewed as mere guidelines, and are not intended to be taken as legal advice. Many bold statements have been made in this article in this regard, but it must be remembered that, since there are no black and white guidelines on copyright as it effects terminography and lexicography, every case brought before a court of law shall be tried on its own merit, and one cannot predict clear verdicts for the multitude of problematical copyright issues that may surface in the course of our work. The best advice for parties working together on projects is to enter into contracts to protect their mutual rights.

\section{Bibliography}

Alberts, M. 1990. ' $n$ Bepaling van Afrikaanse vakleksikografiese behoeftes. Unpublished D. Litt. et Phil. Thesis. Pretoria: UNISA.

Bergenholtz, J. and S. Tarp. 1995. Manual of Specialised Lexicography. Amsterdam: John Benjamins.

Cluver, A.D. de V. 1992. Die verskille en ooreenkomste tussen algemene leksikografie en vakleksikografie in die praktyk. Pretoria: Nasionale Terminologiediens.

Copeling, A.C.J. 1978. Copyright and the Act of 1978. Durban: Butterworths. 
Felber, H. 1986. Einige Grundfragen der Terninologiewissenschaft aus der Sicht der allgemeinen Terminologielehre. Special Language/ Fachsprache 8 (3-4): 110-123.

Galinski, C. 1996. Terminology and Copyright. TermNet News 52/53: 7-15.

General Agreement on Tariffs and Trade (GATT). 1994. Final Act Embodying the Results of the Uruguay Round of Multilateral Trade Negotiations. Marrakesh: GATT Secretariat.

Gervais, Daniel. 1995. Protection of Copyright on the Information Highway. TermNet News 50/51: 1-4.

ISO DIS 12620: 1995. Terminology-Computer-Applications-Data Categories. Geneva: ISO.

Jerrard, H.G. and D.B.McNeill. $1972^{3}$. A Dictionary of Scientific Units. London: Chapman and Hall.

Kommission der Europäischen Gemeinschaften. 1995. Grünbuch. Urheberrecht und verwandte Schutzrechte in der Informationsgesellschaft. Luxembourg: KEG.

Lehman, B. 1995. The Report on the Working Group on Intellectual Property Rights. Intellectual Property and the National Information Infrastructure (ITTF). Available as an ASCII file from http://www.iitf.doc.gov or as a PDF file from the U.S. Patent and Trademark Office WorldWide Web site http://www.uspto.gov

Norman, S. 1994. Copyright: Legal Protection of Databases. IFLA Journal 20(4): 459-461.

Report of the AAU Task Force on Intellectual Property Rights in an Electronic Environment. 1994. Washington, DC.

RJ Romme vs. Van Dale Lexicografie BV (Hof, Den Haag, April 1, 1993) [1994] NJ 224.

Romeo, James J. 1997. Language and the Internet. Language International 9 (1): $20-21$.

South African Copyright Act 98 of 1978 (as amended). Pretoria.

Templeton, B. 1996. 10 Big Myths about Copyright Explained. http://www.clarinet.com/brad/ copymyths.html

Trittipo, M. 1996. A Primer on Translations and Copyright. Global Vision: Proceedings of the 37th Annual Conference of the American Translators Association. October 30 - November 3, 1996: 367371. Colorado Springs.

United States Copyright Protection Act of 1988. Washington, DC.

World Intellectual Property Organization (WIPO). 1995. Berne Convention for the Protection of Literary and Artistic Works. Paris. Act of July 24, 1971, as amended on September 28, 1979. Geneva.

Wright, S.-E. 1995. Copyright Issues affecting Terminology in Electronic Environments. Brunnstein, K. and P.P. Sint (Eds.). 1995. Intellectual Property Rights and New Technologies: Proceedings of the Knowright '95 Conference: 253-258. Österreichische Computer Gesellschaft. Vienna/ Munich: R. Oldenbourg.

Wright, S.-E. 1996. Intellectual Property Rights and Terminology Management. TermNet News 52/53: 1-6.

\section{Consulted}

Ms Monica Seeber, Publishing Consultant: South African Press Association (South Africa).

Ms Sue Butler, Chief Editor: Macquarie Dictionary (Australia).

Ms Sue-Ellen Wright, Managing Editor: TermNet News (Austria, USA).

Mr Von Burton Dursham, The Registrar: Patents, Hallmarks, Authors' Rights and Models, Department of Trade and Industry (South Africa). 